\title{
CUNeGEO
}

International Journal of Environment and Geoinformatics (IJEGEO) is an international, multidisciplinary, peer reviewed, open access journal.

\section{Shipwreck cargoes in the Balearic Islands: the Hellenistic reliefware as indicator of maritime trades in the Western Mediterranean}

\section{Paola PUPPO}

\author{
Chief in Editor \\ Prof. Dr. Cem Gazioğlu \\ Co-Editors \\ Prof. Dr. Dursun Zafer Şeker, Prof. Dr. Şinasi Kaya, \\ Prof. Dr. Ayşegül Tanık and Assist. Prof. Dr. Volkan Demir
}

Editorial Committee (June 2021)

\begin{abstract}
Assoc. Prof. Dr. Abdullah Aksu (TR), Assit. Prof. Dr. Uğur Algancı (TR), Prof. Dr. Bedri Alpar (TR), Assoc. Prof. Dr. Aslı Aslan (US), Prof. Dr. Levent Bat (TR), Prof. Dr. Paul Bates (UK), İrşad Bayırhan (TR), Prof. Dr. Bülent Bayram (TR), Prof. Dr. Luis M. Botana (ES), Prof. Dr. Nuray Çağlar (TR), Prof. Dr. Sukanta Dash (IN), Dr. Soofia T. Elias (UK), Prof. Dr. A. Evren Erginal (TR), Assoc. Prof. Dr. Cüneyt Erenoğlu (TR), Dr. Dieter Fritsch (DE), Prof. Dr. Çiğgem Göksel (TR), Prof.Dr. Lena Halounova (CZ), Prof. Dr. Manik Kalubarme (IN), Dr. Hakan Kaya (TR), Assist. Prof. Dr. Serkan Kükrer (TR), Assoc. Prof. Dr. Maged Marghany (MY), Prof. Dr. Michael Meadows (ZA), Prof. Dr. Nebiye Musaoğlu (TR), Prof. Dr. Masafumi Nakagawa (JP), Prof. Dr. Hasan Özdemir (TR), Prof. Dr. Chryssy Potsiou (GR), Prof. Dr. Erol Sarı (TR), Prof. Dr. Maria Paradiso (IT), Prof. Dr. Petros Patias (GR), Prof. Dr. Elif Sertel (TR), Prof. Dr. Nüket Sivri (TR), Prof. Dr. Füsun Balık Şanlı (TR), Prof. Dr. Uğur Şanlı (TR), Duygu Ülker (TR), Prof. Dr. Seyfettin Taş (TR), Assoc. Prof. Dr. Ömer Suat Taşkın (TR), Assist. Prof. Dr. Tuba Ünsal (TR), Dr. Manousos Valyrakis (UK), Dr. İnese Varna (LV), Dr. Petra Visser (NL), Prof. Dr. Selma Ünlü (TR), Assoc. Prof. Dr. Oral Yağcı (TR), Prof. Dr. Murat Yakar (TR), Assoc. Prof. Dr. İ. Noyan Yılmaz (AU); Assit. Prof. Dr. Sibel Zeki (TR)
\end{abstract}




\title{
Research Article
}

\section{Shipwreck cargoes in the Balearic Islands: the Hellenistic reliefware as indicator of maritime trades in the Western Mediterranean}

\author{
Paola Puppo \\ MIUR, Ministero dell'Istruzione, Università, Ricerca
}

E-mail: paola.puppo@katamail.com

$\begin{array}{llll}\text { Received: } & 11 & \text { Sept } & 2020 \\ \text { Accepted: } & 07 & \text { Dec } & 2020\end{array}$

How to cite: Puppo, P. (2021). Shipwreck cargoes in the Balearic Islands: the hellenistic reliefware as indicator of maritime trades in the western Mediterranean, International Journal of Environment and Geoinformatics (IJEGEO), 8(2):126-134. doi: 10.30897/ijegeo.793930

\begin{abstract}
The wreck of St. Jordi (near the island of Majorca in the Balearic Islands) documents in the hold the presence of a bowl signed by the potter Lapius, active in central Italy in the II century BC. The wreck of St Jordi, left from a port of the Ionian (Pergamo, Rhodes?), can have stopped in the port of Ostia, depositing rhodian wine amphorae and loading black gloss ware, and other materials, in addition to Italo - Megarian ware, directed to the Iberian Peninsula. In his cabotage, the ship should have coasted the Balearic Islands, and then from Ebusus (Ibiza) to the port of Cartagena in which to download the content of the cargo hold. But the journey of the ship has been arrested in front of Majorca after a terrible storm that has wrecked the ship with its cargo before being able to arrive in the harbor. Another maritime itinerary could have been from the emporion of Delos with a stop in a port of Apulian, through the strait of Messina, and then to reach the port of Ostia, from where to leave again crossing the channel north Sardinian near the Spargi island and then to head towards the Balearic Islands, transporting, among other goods, Hellenistic relief ware of Ephesian production (from the Monogram workshop), as prove the megarian ware found in the Cales Coves in Menorca and the four bowls in the graves of the necropolis of Puig des Molins in Ibiza.
\end{abstract}

Keywords: Wreck, Balearic Islands, Italo-Megarian Ware, Hellenistic Reliefware, Ephesian Production

\section{Introduction}

Two fundamental models have been proposed for maritime trade: cabotage and directed trade through emporia. This is not a question of whether ships sailed along the coast or out of sight of land, but rather a question of the scale of trade, the level of forethought and planning which went into the composition of the cargo, and the degree of information available with regard to markets. Shipwrecks are primarily a record of heavy, durable cargoes - first and foremost amphoraborne goods, but also stone, metal ingots and, to a lesser extent, other ceramics. Cargoes of textiles, grain and other organic materials, which certainly existed, are rarely visible. The principal surviving cargo of most wrecks is amphorae, which are extremely durable. Stone is another long-lasting cargo, though such wrecks are still far fewer in number than ships carrying chiefly amphorae. As the food commodities (chiefly wine, oil and salted-fish products) that travelled in amphorae were one of the major categories of traded goods in the Roman world, they are precisely the types of products whose transport is crucial to an understanding of maritime trade (Rice 2016; Öniz et al., 2015).

\section{Materials and Methods}

The wreck of St. Jordi (site of Ses Salinas near the island of Majorca in the Balearic Islands) - fig. 1 - , excavated in 1977 by a team led by D. Cerdà and coordinated by D.
Colls, is a Roman republican ship, about 11-13 $\mathrm{m}$ in length, which was wrecked on a date between 100-80 BC. His shipment was consisting of Campanian wine in amphoras Dressel $1 \mathrm{~A}$ and $1 \mathrm{C}$, Apulian wine in amphoras Lamboglia 2, black gloss ware Campanian B and D, lamps, thin walled and common ware. Fig. 2.

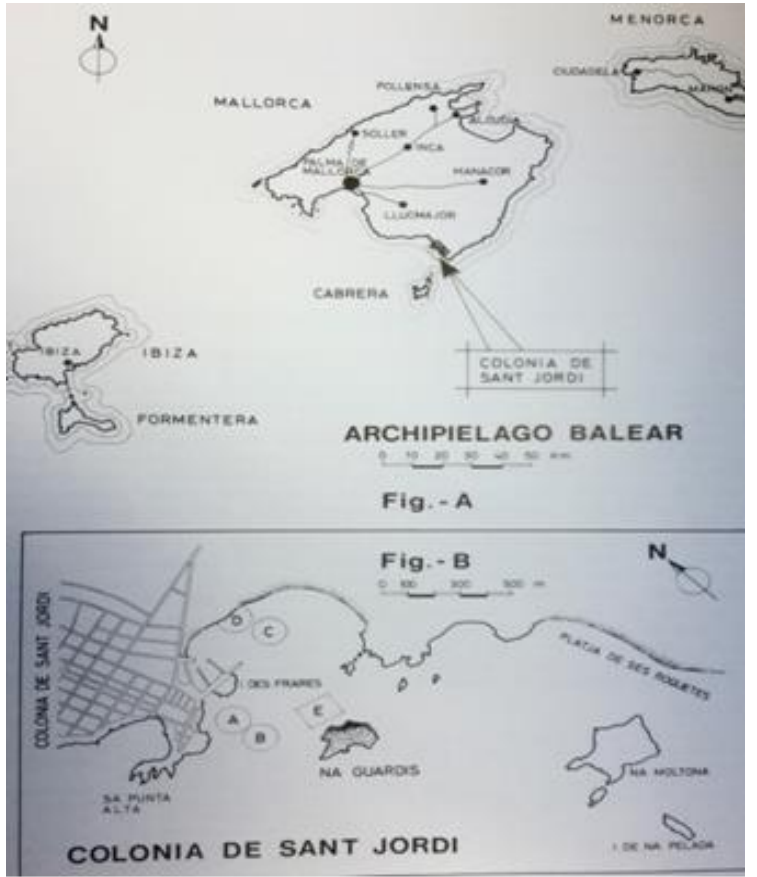

Fig. 1 Map of wreck of Sant Jordi (after Colls 1986) 
The ship documents in the hold, between the load of rhodian amphoras and other goods from the East, the presence of a bowl signed by the potter Lapius, active in central Italy in the II century BC. Fig. 3 The wreck of St
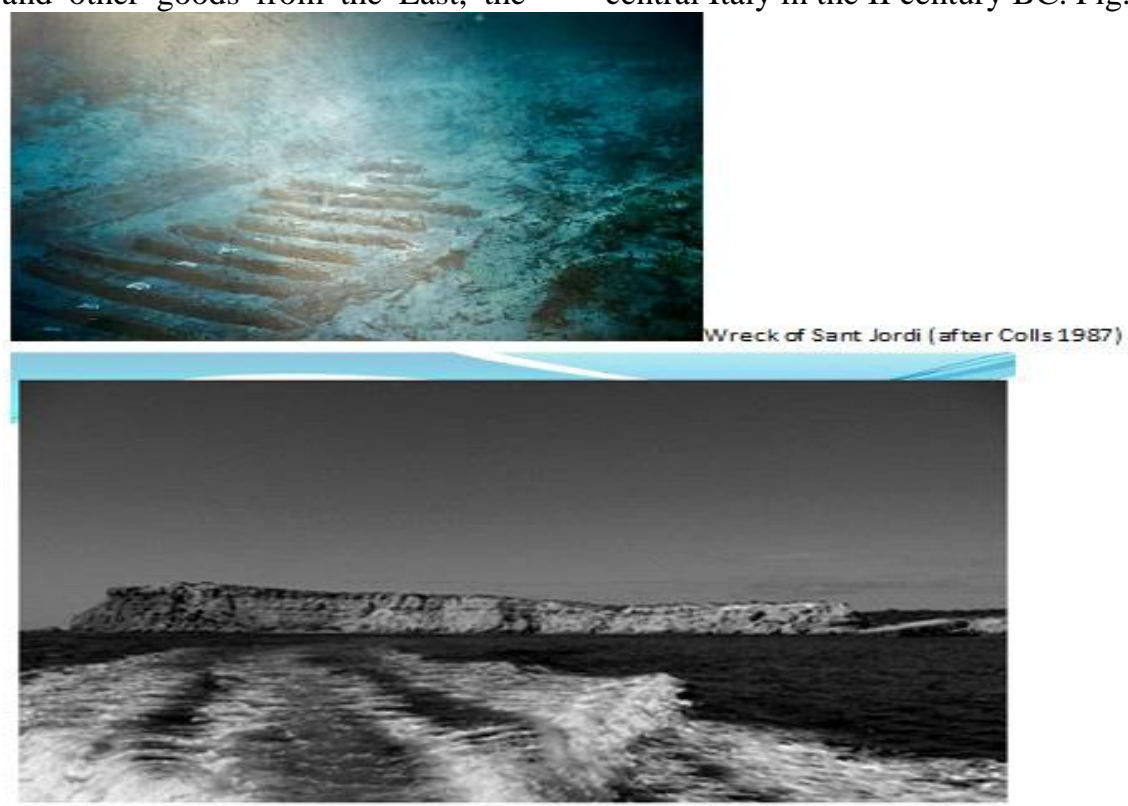

Fig. 2 Wreck of Sant Jordi (after Colls 1986)

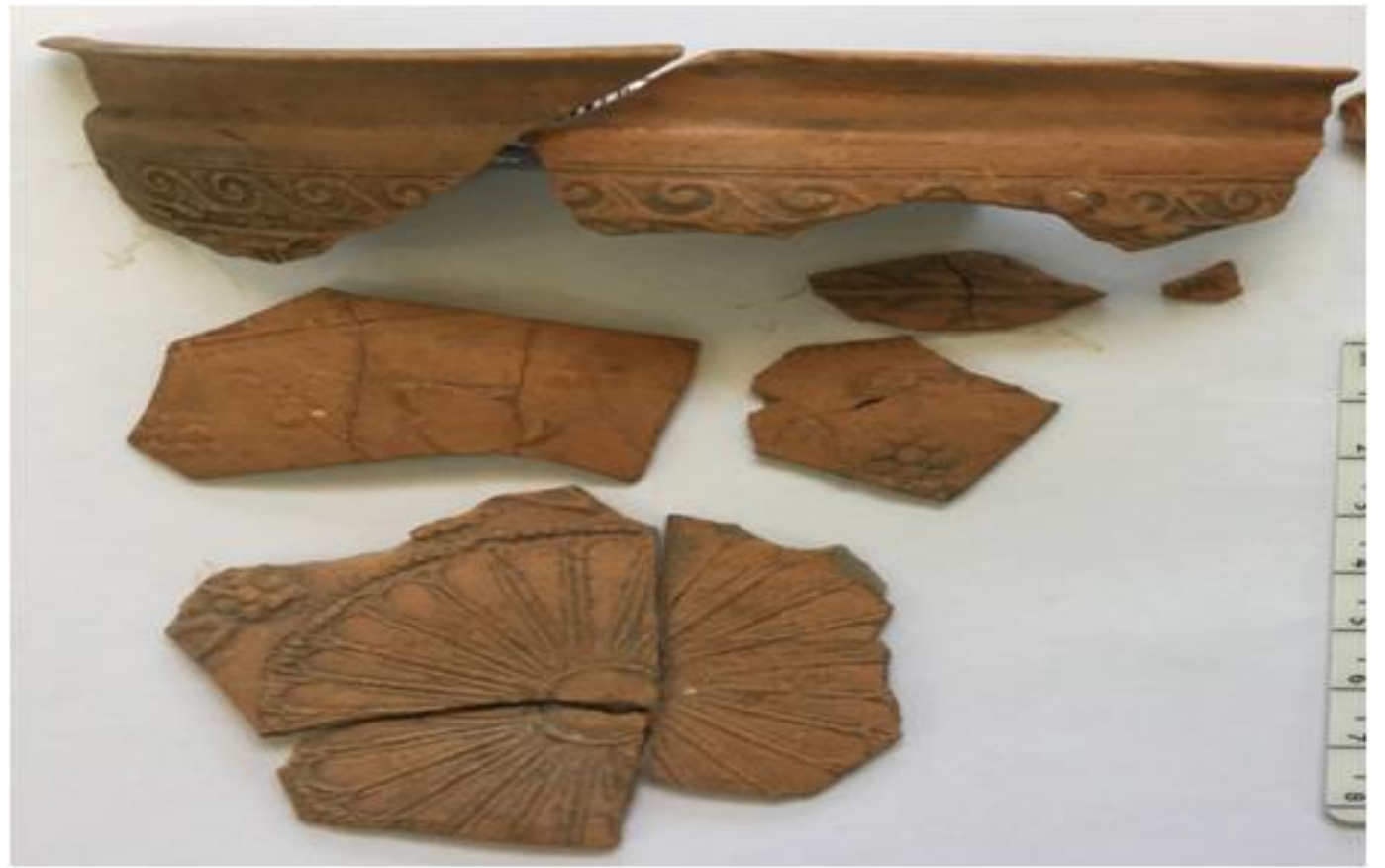

Fig. 3 Photo of bowl signed by Lapius in the wreck of Sant Jordi (Palma de Mallorca, Municipal Museum)

Jordi, left from a port of the Ionian (Pergame, Rhodes?), can have stopped in the port of Ostia, depositing rhodian wine amphoras and loading black gloss ware, pans "a vernice rossa interna", and other materials, in addition to Italo - Megarian ware, directed to the Iberian Peninsula. In his cabotage, after a stop probably in the port of Karales (Cagliari in Sardinia), the ship should have coasted the Balearic islands (Menorca, Mallorca, Ibiza), and then from Ebusus (Ibiza) to the port of Cartagena in which to download the content of the cargo hold and possibly load perhaps lead ingots from the mining region of Cartagena ${ }^{1}$, painted kalathoi of Iberian production

${ }^{1}$ About the trade in branded lead lingots from the mining region of Cartagena to see Stefanile 2013, 9911001 and also Stefanile 2015, 585-592. About the (so-called sombreros de copa) with salted anchovies, amphoras, and then return to the Italic coasts, perhaps in the port of Ostia near Rome. But the journey of the ship has been arrested in front of the island of Majorca after a terrible storm that has wrecked the ship with its cargo before being able to arrive in the harbor. Near the shipwreck of Sant Jordi is the wreck Es Carbó II with a shipment of amphoras Dressel 1A (Pons 2005).

On the ship - perhaps among the captain's on-board equipment- there was also a bowl in italo-megarian ware signed by Lapius, a potter operating in central Italy: the location of his workshop is uncertain but it could be

importance of the mining sector in the history of Iberian Peninsula, see Vargas 2019. 
located in the area around Viterbo or Orvieto (southern Etruria) or be connected to the figulinae of Tivoli (Tibur) near Rome (Leotta 2017). Its activity begins around
$120 / 110$ BC. The fabric of this bowl is very fine and purified, of colour orange Fig. 4 (diameter of the rim 11 $\mathrm{cm}$, height $6.5 \mathrm{~cm}$ ).

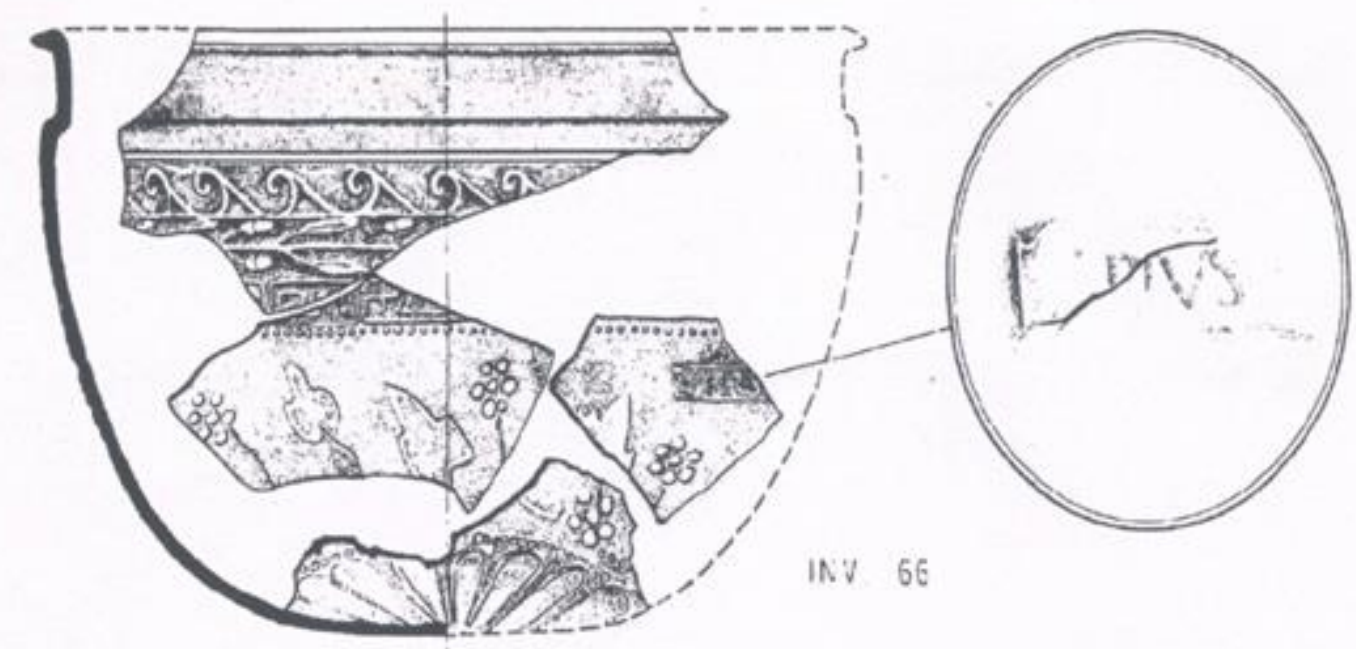

Fig. 4 Bowl signed by Lapius in the wreck of Sant Jordi. Drawing.

Under the rim, is a frieze with volutes running to the left, followed by a sprig of myrtle directed to the right and a double meander intertwined (within the spaces left free by the play of lines there is a motif of small squares). A row of full pearls separates the border decoration from the central part of the bowl, which has a trilobed flower motif on wavy stems alternating with flowers of seven circular petals (similat to full pearls) on a thin stem. In a rectangular cartouche there is the retrograde molded signature of the potter C. Lapius. A second row of full pearls introduces to the area of the bottom of the bowl decorated with a circular shield medallion surrounded by a ray of flutings (godrons narrow and rounded at the top). In the Iberian Peninsula, the Italo-megarian ware, in addition to the specimen of the wreck of Sant Jordi is attested in Empuriès (the famous greek colony of Ampurias), with a bowl attributable to the production of Popilius published in 1953-1954 by Mercedes Vegas, but now no longer available neither to the Archaeological Museum in Empuriès and in the Archaeological Museum of Barcelona; in Tarragona with a fragment of bowl decorated with godrons and signed by Herakleides, another potter who had his workshop in Tibur (Tivoli, Rome) (Leotta 2017)

At the entrance of the port of Cabrera on the Island of the same name, south of Mallorca, several wrecks have been found which testify to the existence of a maritime route linking the Iberian Peninsula to Italy, between the south of the Balearic Islands and the strait of Bonifacio. Around to 1960 the Cabrera II was explored, relative to a merchant who would have started from Ebusus, probably in the context of the Second Punic War, with a shipment made up of Punic-Ebusian amphoras $\mathrm{T}$ 8.1.3.1, North African Punic T-7.2.1.1., T-5.2.3.2 and Mañá B-1, amphoras greco-italiche and even a Punic Maltese amphora Merlin /Drappier -3 (Colom Mendoza 2016). The secondary cargo would consist of black gloss ware (among these a plate of Lamboglia 26c from the workshop of the three radial palmetas of Rhode, a guttus Lamboglia 45), a louterion and common Ebusitan pottery. Three lead lingots, that they come from Cartagena mining area as document the isotope analysis, were located inside shells of Pinna Nobilis lamelibranchs, weighing between 31 and $40 \mathrm{~kg}$. Exalting the mineral resources of southern Iberia was a constant in ancient descriptions of the region, which, almost from the time of conquest, frequently alluded to the abundance and quality of metals in the region. In the first century BC, Diodorus (5.36), following Posidonius, wrote that 'after the Romans had made themselves masters of Iberia, a multitude of Italians have swarmed to the mines and taken great wealth away with them, such was their greed'. In the mid- second century BC, according to this author, 40,000 men were working in the mines of Carthago Nova, providing the state a net benefit of 25,000 drachmas per day (Strab. 3.2.10). Pliny, in the second half of the first century AD, stated that Spanish silver was the most beautiful and that it could be found on barren ground and even in the mountains (Pliny $n h$ 36.97). Mining, along with military service, has traditionally been considered one of the main causes of Italian migration to Iberia during the last centuries of the Roman Republic. The armies were followed by mercatores, suppliers, tax farmers, and other 'professionals', who did business during campaigns and even collaborated with the administration in the management of conquered territories.

\section{Results}

During the roman republican period increased the maritimes trades from the Iberian Peninsula and the Italic coasts trough the Balearic Islands because Quintus Cecilius Metellus conquered the Balearic Islands in 123 BC (Strabo III, 5,1) and established, at least two military camps in Mallorca: the first in the area that occupies the current Son Espaces Hospital in Palma and another 
possibly in Ses Salines. In the context of the Sertorian Wars, the cities were founded, with the status of colony; of Palma and Pollentia for ensure control of the island's three bays that is in an unbeatable position to control maritime traffic (Colom Mendoza 2016).

Another wreck that confirms the existence of a route through the Balearic Islands to the port of Ostia and the italic coasts generally is the Cabrera V, located at $42 \mathrm{mt}$ on the bottom at the entrance to the port of Cabrera on the island of the same name, south of Mallorca; it contained 16 amphoras Derssel 7-11 dated to the end of the 1 st century BC and in use until to the first century A.D. , in addition to the more substantial load that the ship was carrying, that is 40 lead lingots probably coming from Cartagena. There are other wrecks such as Cabrera I, which transported African and Lusitanian amphoras dated to the second centuty AD, Cabrera 3 (with amphoras Dressel 20 and Dressel 23 from Betica, Lusitanian and African amphoras dated to the 2nd century AD), Cabrera 4 (first quarter of the 1 st century $\mathrm{AD}$, found at Moro Boti), Cabrera 6 (containing lead lingots of the Vespasian period). ${ }^{2}$

After all, a commercial route that linked the port of Ostia to that of Cartagena with products that started from Ostia (such as Italic wine amphorae, black gloss ware, common ware, mortars during the late republican period and later -in the imperial period, also italic terra sigillata (TSI) - towards the Iberian peninsula and Iberian products towards the port of Ostia is documented by the presence in Rome of betic amphorae (Dressel 20, Dressel 4/11, Dressel 7/11) containing oil, Hispanic food products (in the Gaditanian types T-7.4.3.2/T7.4.3.3, in the Pellicer D amphorae), by kalathoi-sombreros de copa with decorations painted on the surface exterior, ampuritane grey ware. ${ }^{3}$

Underwater archaeology has long documented the trade of tarraconese wine transported in dolia by ships which also reached the ports of central Italy. This type of trade seems to be linked to the initiative of gens of Minturnae, that of the Pirans, mentioned by the stamps on the dolia: this "loose" wine was however of inferior quality compared to that transported in amphorae in the cargoes. (Heslin 2011).

In the island of Menorca, Hellenistic relief ware has been found in two sites: in the eastern part of the Island, in the sanctuary of Son Domingo in Ciutadella (fig. 5), and in the southern part- five $\mathrm{km}$ from the capital of the island (Menorca)- in the site of Calescoves, a sanctuary in a cave. As in the sanctuary of Son Domingo, the Hellenistic relief ware was used for ritual libations. The

\footnotetext{
${ }^{2}$ Colls, Domergue, Guerrero Ayuso 1986, 31-80.

${ }^{3}$ About the iberic painted ware (kalathoi and sombreros de copa) to see the findings in Rome in the excavations of Meta Sudans and in the necropolis of Serenissima in contexts of late II century BC - first half of the first century BC: Caspio 2009, 486, Tav. VI, n.1-4. In addition, for the production of amphorae to see the contribution of Rizzo, Moreno Megías 2019, 23-38.
}

bowls found in the sanctuary of Son Domingo are three and probably come from Ephesus: the bowl nr. 1 has fabric gray and matt black gloss (diam. rim $14 \mathrm{~cm}$, high $10 \mathrm{~cm}$ ), under the rim (indistinct, thinned and rounded in the upper part) there is a frieze between two raised strips with six-petal rosettes and pistil central, another frieze follows with pairs of opposing palmettes alternating with eleven-petal rosette. This motif is similar at a bowl found in Ephesos (Dereboylu 2001, Tav. 16 nr. 108). Around the base is a smooth circular medallion (diam. $6 \mathrm{~cm}$ ) surrounded by a corolla of palmette leaves with a rounded top with evident lateral ribs. The bowl nr. 2 (rim diameter $12 \mathrm{~cm}$, high $9 \mathrm{~cm}$ ), Inv. 725, has a gray fabric and dark gray matt; under the rim (of the same type as the previous bowl) is a frieze with six-petal rosettes, followed by a narrow band with rounded double "s" motifs with a left-hand trend; the central part of the bowl is occupied by a decoration with imbricated leaves. The circular bottom is smooth. The bowl belongs to the Menemachos workshop (Laumonier 1977, Tavv. 106107).

About the third bowl (inv. 726) remains only the rim (diam. $12 \mathrm{~cm}$ ) and a frieze with five-petal rosettes and central pistil.

In the Jurats Cave of Calescoves, the excavation inside a very deep cave determined that the finds of Hellenistic Relief Ware were very fragmentary, except for a bowl $\grave{a}$ bossettes, of Ephesian production (Dereboylu 2001, Tav. $\left.17 \mathrm{n}^{\circ} 122, \mathrm{n}^{\circ} 125, \mathrm{n}^{\circ} 126, \mathrm{n}^{\circ} 128\right)$, as another bowl with border double verticals "s" and a bottom with embricate leaves of Menemachos workshop (fig. 6), who worked probably in Ephesos. The bowl inv. 08/2012-14/7-54/7$58 / 7$, for the type of decoration, characterized by a row of heart-shaped leaves in horizontal position to right and decoration à bossettes belongs to Philon workshop (Laumonier Tav. $60 n^{\circ} 4259$, Tav. III $n^{\circ} 4187, n^{\circ} 4189$, $\mathrm{n}^{\circ} 4252$ ). Another fragment of bowl presents a motif of six-petal rosettes under the rim, followed by a vegetable motif composed of two opposing palmettes alternating with a rosette of nine petals, finally a corolla of leaves with rounded palmettes, smooth medallion, belongs to the workshop of Monogramma in Ephesos. In Mallorca finds of Hellenist relief ware are also in Son Carriò and in Pollentia (Jaeggi 2000).

The massive arrive of individuals from Italy to the new provinces of Hispania starting from the beginning of the second century $\mathrm{BC}$, following the Roman conquest of the Iberian Peninsula, is a historical phenomenon well documented by the ancient sources and archaeological evidences left by the first Italic who follow the legions of Rome or for trades in the cities, already indigenous, Greek, Phoenician, Punic settlements or foundations $e x$ novo.

In Ibiza from the necropolis of Puig des Molins, from three distinct burials, three Hellenistic relief bowls document the existence of a strong Greek community among the Punic and local ones. The bowl with a frieze of heart-shaped leaves alternating with darts, followed by a band with a motif of bunches of myrtle leaves and 
groups of three full pearls arranged in a triangle as a filler in the spaces left free by the play of the bunches of myrtle; the central part of the bowl is occupied by acanthus leaves alternating with rhomboid leaves with central rib. This bowl can be attributed to the production in Ephesos.

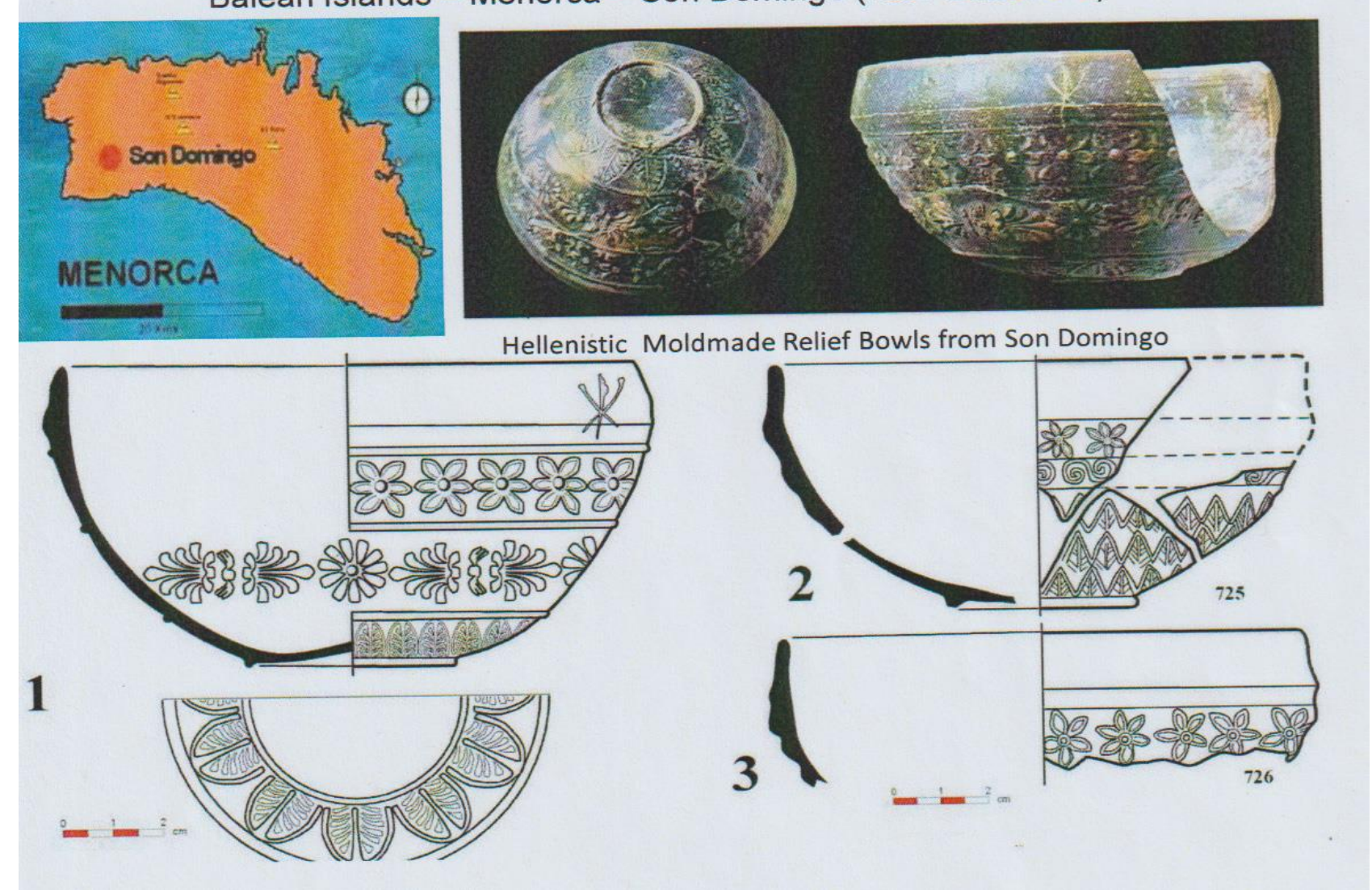

Fig. 5 Sanctuary of Son Domingo in Ciutadella - Menorca (after de Nicolàs Muscaró 2018).
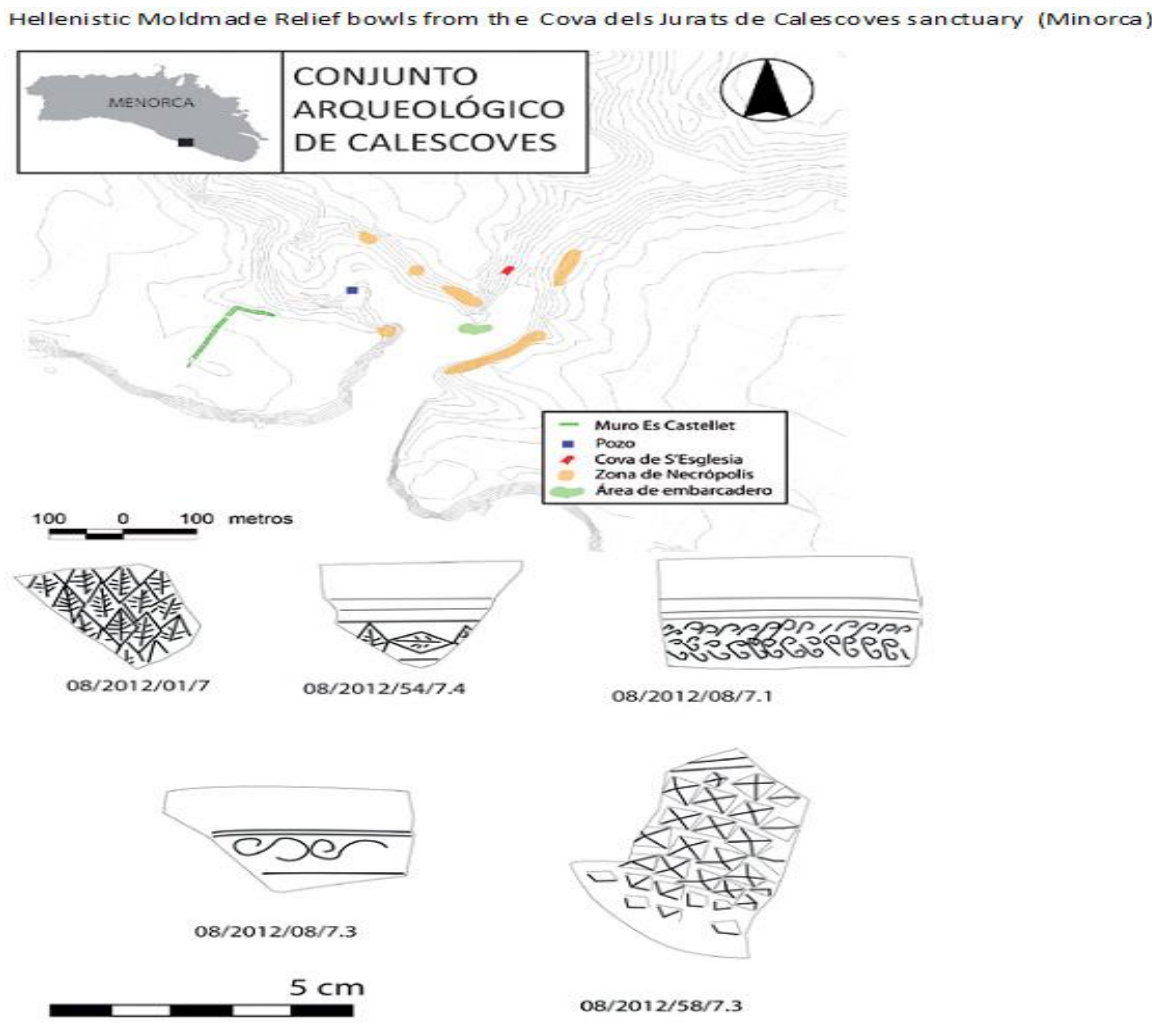

Fig. 6. Menemachos workshop 

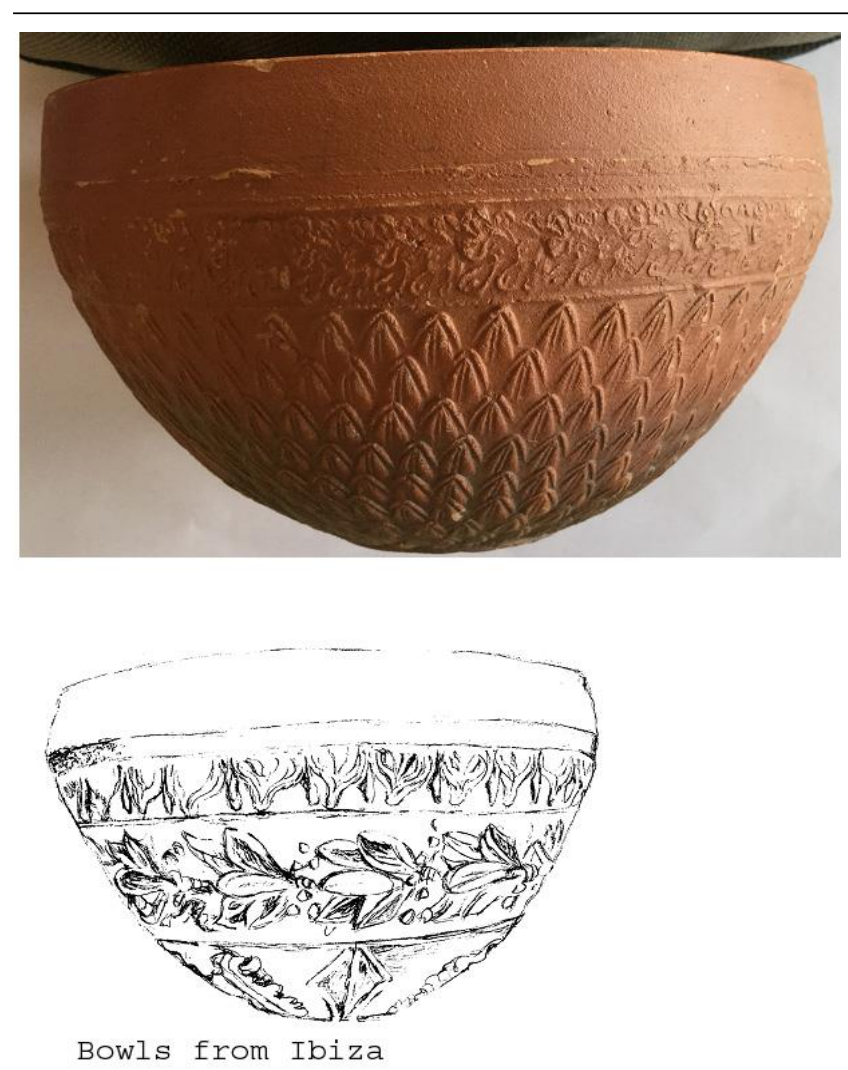

Fig. 7 Ibiza, Necropolis of Puig des Molins Archaeological Museum.

The bowl nr. 2 belongs to the Monogramma workshop, with the classic double meander intertwined with the socalled Saint Andrew crosses in the squares within the game of the meander lines used as fillers; the central part of the bowl is decorated by acanthus leaves with the tip bent to the left and beaded central rib alternating with nymphaea coerulea leaves with simple central rib (for a specimen similar to see Laumonier 1977, Tav. $30 \mathrm{nr}$. 1976, datede to the second century BC) .The third bowl, decorated with embricates leaves, is pertinent to the production of Menemachos (Laumonier 1977, Tav. 106107).

For shape and type of decoration, the bowls found in the necropolis of Puig des Moulins in Ebusus (Ibiza) fall into the production of Ionia, id-est these are bowls of ionian-ephesian production, dated to the second century BC.

This production dominated the western markets through a dense commercial network well organized by mercatores through the emporion of Delos with the support of Italic negotiatores.

Another maritime itinerary could have been from the emporion of Delos with a stop in a port of Apulian, through the strait of Messana, and then to reach the port of Ostia, from where to leave again crossing the channel north Sardinian near the Spargi island and then to head towards the Balearic Islands, transporting, among other goods, Hellenistic relief ware of Ephesian production (from the Monogram workshop), dated to the second century BC.
Spargi's ship contained materials dating from between 120 and $100 \mathrm{BC}$ which are divided into different groups: the load of amphorae (about 400) including Dressel $1 \mathrm{~A}$ and Dressel 1B with Campanian wine, some specimens of Dressel 1C (but in lesser quantity), Dressel 28 and rodian amphorae, plates in black gloss ware (Campanian B) from the Calés area (in Campania) at the end of the 2nd century BC, materials included in the on-board equipment (black gloss ware Campana A, lamps, unguentaria fusiform, some fragments of Hellenistic relief ware), applied relief ware from Pergame (Pergamene applique ware), bowls in Eastern Sigillata A (ESA), common ware, thin walled ware, pans in "ceramica a vernice rossa interna", Hellenistic braziers with Silenus head), materials pertaining to the crew (necklace elements, three bone fives, dices for the play, buttons, amulets, ridges needles) ${ }^{4}$. The ship before landing near the coasts of Ager Falernus (in Campania) where he would have embarked the wine containers and the black gloss ware (Campana A), and then continued towards Spain through the mouths of San Bonifacio, had certainly left from the port of Delos where he had embarked material of oriental origin (the Hellenistic relief ware of ionic-ephesian production - of the Monogram Workshop-, the Eastern Sigillata A (ESA), the relief ware pergamene), but probably also luxury goods such as a marble labrum, an aedicula above column in white Greek marble, a bronze tripod, a candelabrum also in bronze (Beltrame 1998), objects perhaps destined to furnish a luxury domus.

\section{Discussion and Conclusion}

Both the Spargi and Sant Jordi ships show affinity in the loads, especially of pottery (amphorae, hellenistic relief ware, thin walled ware, common ware, eastern terra sigillata ESA) and document the marketing methods of import of products from Orient (Asia Minor), which evidently traveled with continuous stops along the Tyrrhenian ports (Parker 1992). In any case, the importance of the port of Delos emerges, an emporion in which the most varied products of the new Roman province of Asia Minor (created in 133 BC) converged, which saw an increase in commercial activities and the strengthening of the port of Delos just between 130 and $120 \mathrm{BC}$.

Pointing the attention to the Hispanian Sardinian route we can add arguments in support of the routes of the cargoes that from the Iberian Peninsula followed the route of the Balearic and Mouths of Bonifacius to arrive in Rome, using the mistral wind, as proved by Blazquez 1968, who notes that the important commercial ports were in late republican period Ampurias (Pol., 3, 76), Tarraco (Liv. 21), Carthago Nova and the Balearic Islands (Strabo, 3).

\footnotetext{
${ }^{4}$ The wreck of the roman ship of Spargi, located by local fishermen in 1957, was the subject of the first excavation campaign in 1958 under the direction of Prof. Nino Lamboglia: Pallares Salvador 1986.
} 
The greek geographer Strabo (3) writes that the surplus products from the Baetica region are sold to the numerous trading ships and he affirms that all the Baetic trade, both import and export, was maritime, either through rivers, through openings, or through channels, all navigable, by large ships or by smaller ones $(3,143)$. The export of Baetic products is well reflected of the large number and large size of the ships, the largest cargo ships that arrived in Pozzuoli (3) and Ostia, all of which presupposes not only a great export trade, but also being organized as a great capitalist company with large arsenals for the construction of ships, a large number of technicians, trade corridors, etc.

The Punic experience certainly helped to establish a route from Nova Carthago to the two most important Sardinian ports on the west coast, Tharros and Sulcis.

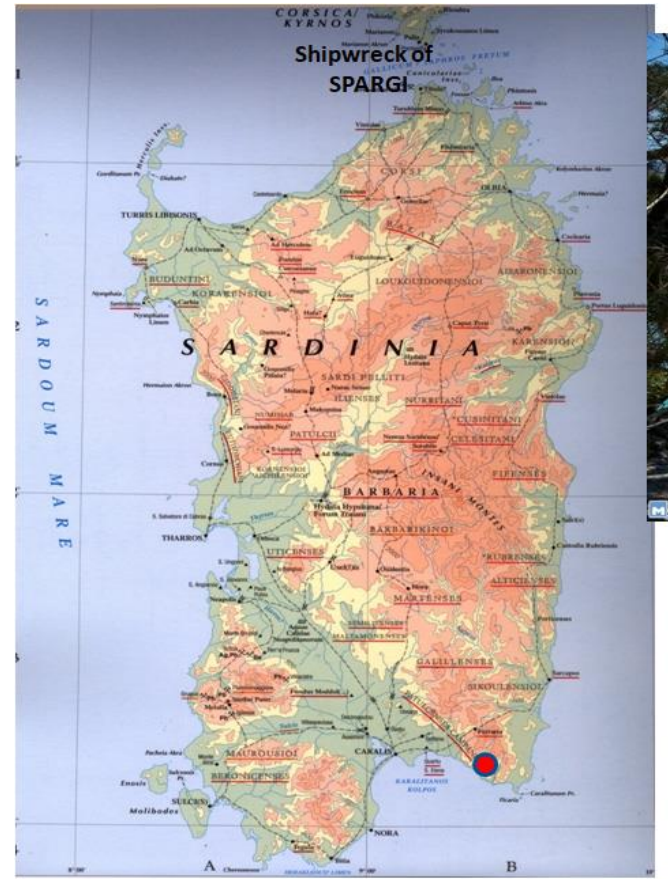

Fig. 8. Sardinia and Spargi’s Islands.

\section{Acknowledgements}

I would like to thank Prof. Oktay Eser Orman, Prof. Elif Nur Ambarkaya and Prof. Dr. Hakan Öniz for accepting my contribution at the 12th International Symposium on Underwater Research, which was held on the 16th May 2020.

\section{References}

Beltrame C. (1998). Per l'interpretazione del relitto tardo-repubblicano di Spargi. Rivista di Archeologia, 22, 38-45.

Blazquez J. M. (1968). Relaciones marítimas entre Hispania y las regiones del Mediterráneo durante la República Romana. Studi in onore di G. Grosso, II, Torino, 168-191.

Caspio A. (2009). Riflessioni sul suburbio orientale di Roma. I contesti tardo-repubblicani di viale della Serenissima e di Quarto del Cappello da Prete. In:
For the routes that reached Rome from Spain, northern Sardinia had a specific support function, since it was preferable to cross the Mouths of Bonifacius. For the routes that from Gades reached Puteoli or that, through Lilybaeum in Sicily headed towards the Mediterranean east, in any case a southern route is more likely, which touched Karales or other Sardinian ports.

Pointing the attention to well dated contexts will help on one hand to add arguments in support of the knowledges about the maritime trade routes and the traffic in the Mediterranean Sea from the coasts of Asia Minor to the Iberian Peninsula. At the same time it is appropriate to consider that the data in our possession are often partial depending on the findings and for this reason they are often conditioned by the external and casual circumstances.

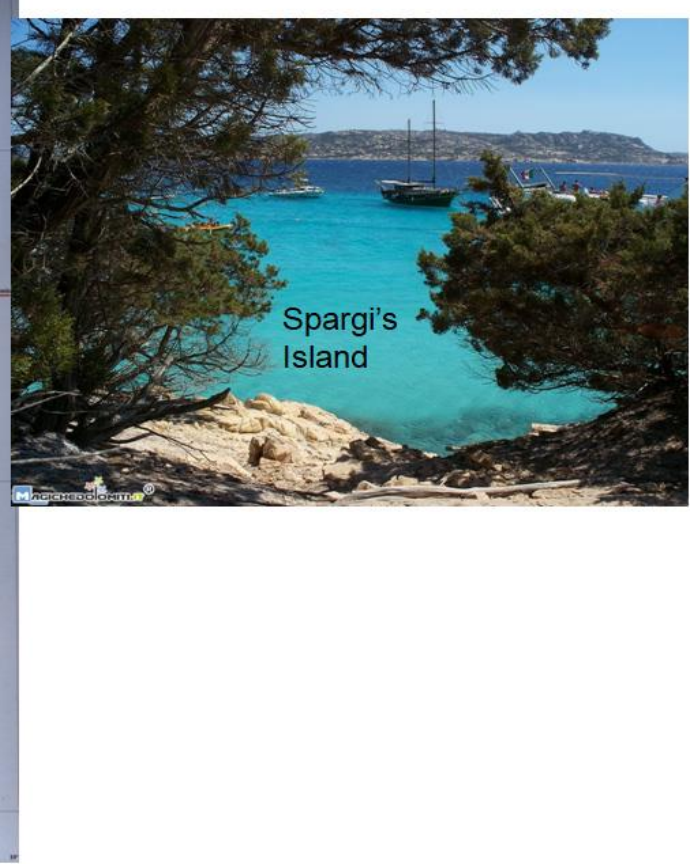

Jolivet V. (eds), Suburbium II (pp. 486-497), Roma: Collection de l'École française de Rome 419.

Colls, D., Domergue Cl., Guerrero Ayuso V. (1986). Les lingots de plomb de l'épave Cabrera 5 (Ile de Cabrera, Baléares). Archaeonautica, 6, 31-80.

Colom Mendoza, E. (2016). La isla de Mallorca (Baleares) dentro de los circuitos comerciales de la Antigüedad. Proceedings of the 5th International Congress on Underwater Archaeology, a heritage for mankind Cartagena, October 15th-18th, 2014, IKUWA V, Cartagena, 574-589.

De Nicolàs Mascaró C. J. (2018). Vidas quotidiana dels romans menorquins. Els bols hellenistics una espècie també present al santuari de Son Domingo, Ciutadella (s.II a.C.). Arqueomenorca, monografies 45, Maó.

Dereboyglu E. (2001). Weissgrundige keramik und hellenistische Reliefbecher aus dem Hanghaus 1. In: Krinzinger F. (Hrsg.), Studien zur hellenistischen Keramik in Ephesos (pp. 21-42), Wien: Ergänzungenshefte $\mathrm{zu}$ den Jahresheften des 
Österreichischen Archäologischen Institutes (ErghÖjh), 2.

Heslin K. (2011). Dolia shipwrecks and the wine trade in the Roman Mediterranean. In: Robinson D-Wilson A. I. (eds), Maritime archaeology and ancient trade in the Mediterranean, Oxford, 157-168.

Jaeggi O. (2000). Der Hellenismus auf der Iberischen Halbinsel: Studien zur iberischen Kunst und Kultur: das Beispiel eines Rezeptionsvorgangs, Mainz am Rhein.

Laumonier A. (1977). La céramique hellénistique à reliefs. Atelier ioniens 1, EAD, XXXI, Paris: Editions Boccard.

Leotta M.C. (2017). La ceramica ellenistica a rilievo dell'Italia centrale. Produzione e diffusione, Roma: Scienze e Lettere.

Öniz, H., Kaya, H., Gazioğlu, C. (2015). Geoarchaeological Researches on the Mediterranean Coast, II. Klyl ve Deniz Jeolojisi Sempozyumu, 133p.

Pallarés Salvador F. (1979). La nave romana di Spargi. Relazione preliminare delle campagne 1977-1980. Rivista di Studi Liguri, 45, 147-182.

Pallarés Salvador F. (1986). Il relitto della nave romana di Spargi. Campagne di scavo 1958-1980. Archeologia Subacquea, 3, Suppl. Bollettino d'Arte, nr. 37-38, 89-102.

Parker A.J. (1992). Ancient Shipwrecks of the Mediterranean and the Roman Provinces, Oxford:Tempus Reparatum (British Archaeological Reports- BAR International Series 580).

Pons, J.M. (2005). El jaciment punico-ebusita de l'illa dels Conills (Cabrera). Mayurqa, 30, 753-779.

Rice C. (2016). Shipwreck cargoes in the western Mediterranean and the organization of Roman maritime trade. Journal of Roman Archaeology, 29, 179-193.

\section{Shipwreck of Spargi}

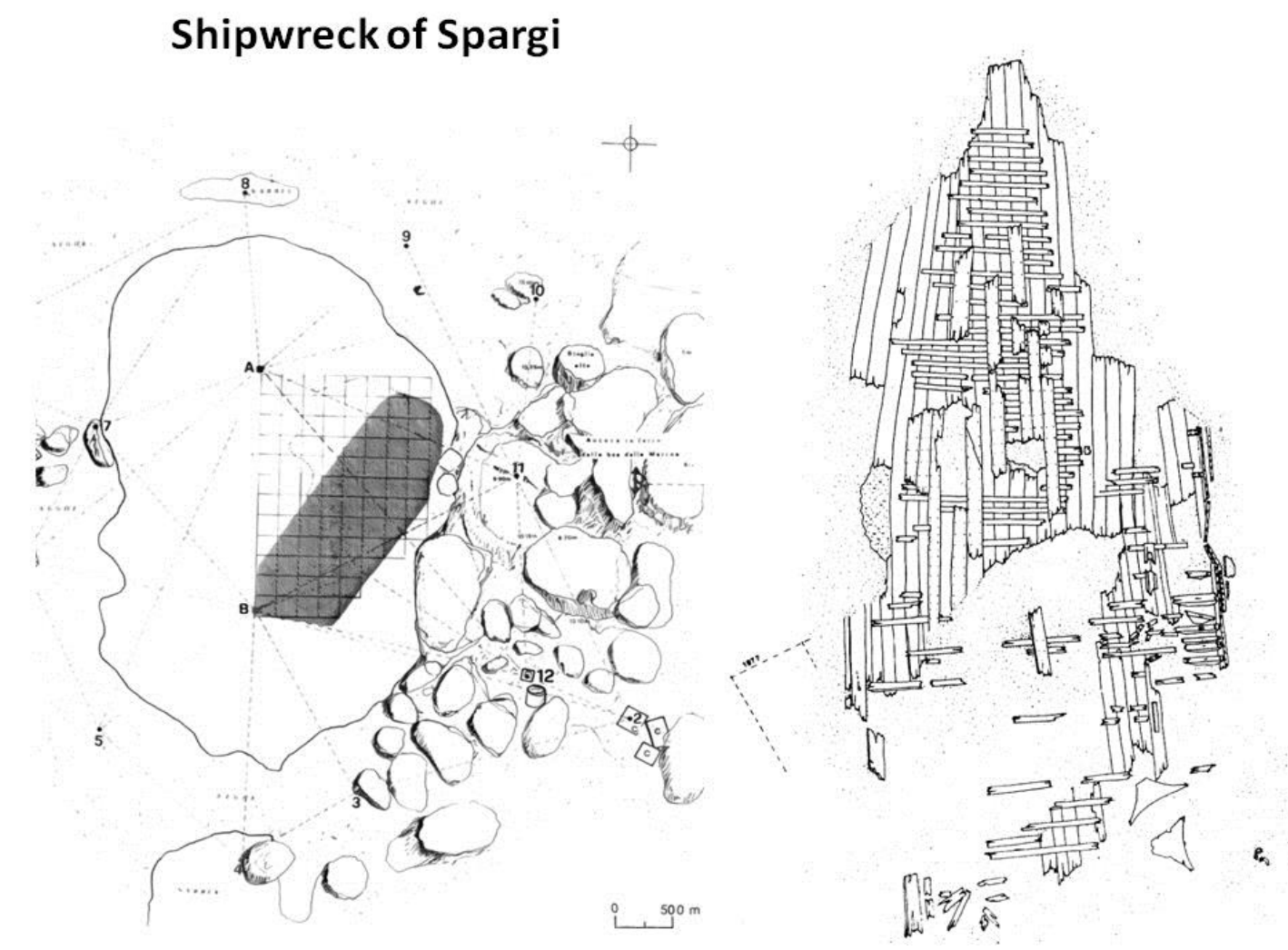

Rizzo G., Moreno Megías V. (2019). Roma e le prime importazioni di alimenti ispanici trasportati in anfora, Journal of Roman Archaeology, 32, 23-38.

Sanchez Lòpez E., Orfila Pons M. (2015). Boles hellenìsticos con relieves a molde en el santuario del Calescoves (Menorca). SPAL-Revista di Prehistoria y Arqueologia, 24, 237-249.

Stefanile M. (2013). On the routes of the Iberian lead. New data and new remarks on the presence of gentes from Campania in Hispania between the II century B.C. and the I century A.D. on the basis of marked lead lingots. In: Bombardieri L., D'Agostino A., Guarducci G., Orsi V., Valentini S. (eds) SOMA 2012 Identity and Connectivity: Proceedings of the 16th Symposium on Mediterranean Archaeology, Florence, Italy, 1-3 March 2012 (pp. 991-1001), Oxford: Archaeopress BAR - S2581.

Stefanile M. (2015). Sailing towards the west. Trade and traders between the Peninsula Iberica and the Campania between the II century B.C. and the I century A.D. In: P. M. Militello - H. Oniz (eds.), SOMA 2011, Proceedings of the GAMA Symposium on Mediterranean Archaeology-Catania 3-5 March 2011 (pp. 585-592), Oxford: Archaeopress BAR S2695 (I).

Vargas G. E. (2018). The Economy and Romanization of Hispania Ulterior (125- 25 bce): The Role of the Italians. In: Andreotti G.C. (eds), Roman Turdetania: Romanization, Identity and SocioCultural Interaction in the South of the Iberian Peninsula between the 4th and 1st centuries BCE (pp. 164-185), Leiden: Brill.

Vegas M. (1953-1954), Dos vasos megaricos de Ampurias, Ampurias, XV-XVI, 352-355.

Fig. 9 Spargi's wreck, drawing (after Pallares 1979). 

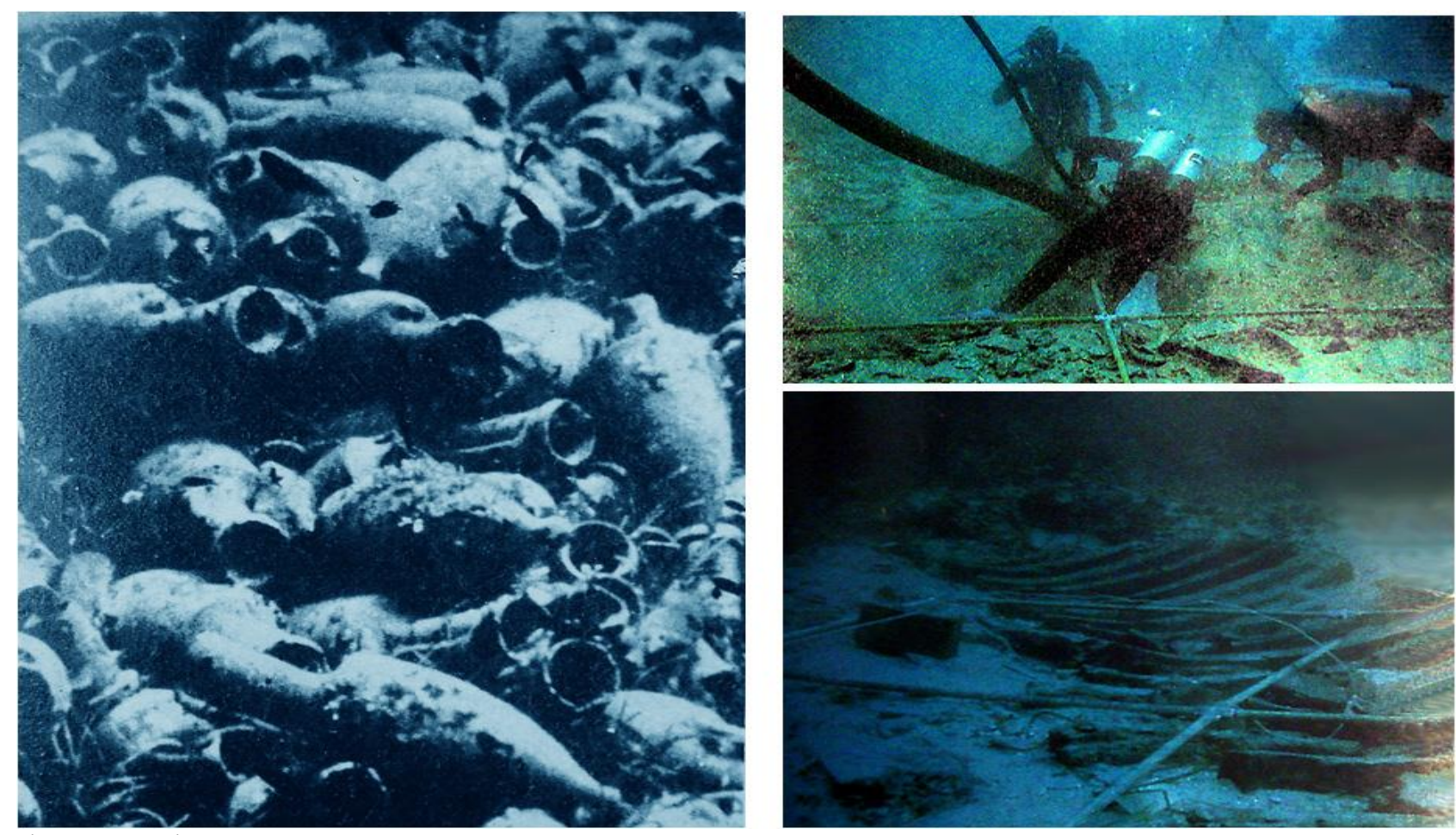

Fig. 10 Spargi’s wreck (after Pallares 1986) 